Natalija Jovanović ${ }^{1}$

University of Niš

Faculty of Philosophy

Milica Jovanović

University of Niš

Innovation Center
Прегледни научни рад

UDK 316.344.23:330.1

Примљено: 20.9.2019.

Ревидирана верзија: 12.3.2020.

Одобрено за штампу: 13.3.2020.

DOI: https://doi.org/10.46630/gsoc.24.2020.01

\title{
POVERTY AND SOCIAL INEQUALITY AS FACTORS OF SOCIAL EXCLUSION
}

\begin{abstract}
This paper deals with the qualitative analysis of poverty and social inequality in contemporary societies and forms of social exclusion of individuals, families and social groups. Indicators of poverty, the causes of poverty, misery index, the standard of living, social stratification, and social exclusion are some of the economic and also sociological categories that are measurable and applicable factors in the analysis of social conditions. Poverty, social inequality and social exclusion give an image of a society as well as a prospect of possible difficulties in social development, potential conflicts, divisions, overt and covert tensions and conflicts. Economic indicators, such as GDP, industrial production index, inflation, unemployment, food basket together with the level of education of the population, the level of achieved democracy, political stability and orientation towards the welfare of the society (responsible social policy), can be a basis for analyzing the perspectives of social inclusion of individuals, families and social groups in specific societies. The work aims to perform an analysis of ideal typical social models as well as to propose measures of social policies to overcome poverty and social exclusion, as growing social problems of the modern world. At this moment, the entire countries of Central Africa are facing a situation in which millions of people are dying of hunger, which is the most extreme form of poverty. These societies are almost entirely excluded from the world community. A form of their inclusion is the engagement in humanitarian actions for providing food, drinking water and health services. This is the first stage of creating the conditions for social inclusion, and the next level is to provide conditions for the education of the population.
\end{abstract}

Keywords: Poverty; social inequality; social exclusion.

\section{Introduction}

Poverty is a problem that destroys social cohesion and causes all kinds of instability and crises. Starting from the first idealistic and utopian theories, to postmodernist ones, social theorists identify poverty as a major problem for the

\footnotetext{
${ }^{1}$ natalija.jovanovic@filfak.ni.ac.rs

${ }^{2}$ jovanovicmilicaa90@gmail.com
} 
functioning of the society. Michel Foucault and the "end of history", Ulrich Beck and the "risk society", Manuel Castells and the "network economy," and Anthony Giddens and "social reflexivity" are just some of the postmodernist theoretical reflections dealing with society, poverty, and crisis. Poverty is an attribute accompanying society in all its temporal and spatial dimensions. Social divisions into classes, layers, strata, or castes accompanied both traditional and modern societies, both pre-civilized and civilized systems. Economic parameters delineated these divisions. As a social indicator, poverty encouraged social division, differentiation, and social tensions, often leading to conflict, both overt and covert.

Poverty is a latent factor of social crisis. As long as the world is divided into the extremely rich and the extremely poor, centers and peripheries, societies will be in a state of general instability, as shown by many extremist incidents in the most developed societies, such as Germany, the Netherlands, or the USA. The migrant crisis and the failure to resolve the problem of traveling poverty, rushing across the sea and barbed wire barriers, brings home the fact that the world community will have to prioritize dealing with the causes in order to solve the visible results of the problem. Poverty is the cause of all causes. The contemporary economic and migrant crises are a global issue which is present in all societies and cultures in the form of poverty or the impoverishment of the populace and increased social inequalities. The crisis is reflected through all institutions and subsystems while the manifestation of the social crisis may have different modalities.

Poverty is a global social problem. Governments, the international community, and world humanitarian organizations are all trying to solve the problem of poverty. The indicators of extreme poverty are visible in real economic indicators, starting from the GDP, inflation rate, unemployment rate, economic growth rates, and the indebtedness index, to visible issues that the population faces on an existential level: hunger, malnutrition, inadequate medical care, shortage of medicine, doctors and health institutions, a deficit of drinking water, inadequate housing, inadequate conditions for raising children, exploiting child labor, discrimination, a large percentage of illiterate and functionally illiterate people, people without necessary qualifications, and a high mortality rate.

The concept of social exclusion as the deprivation of basic human needs, economic poverty, employment, the issue of marginalized or discriminated social groups, the issues of gender equality, and access to education services are all sociological issues that necessarily rely on economic indicators. The platform for a sociological and economic analysis encompasses excluded social groups, the material status of endangered groups, and the social measures that can contribute to social inclusion: education, employment, networking, participation in cultural and social life, and improving the economic situation.

It is possible to divide the crisis into the crisis of economic development, a political crisis and the crisis of democracy, and the crisis of independent social development accompanied by the great forces demonstrating their power. The crisis is always multilayered and multidimensional. It most often emerges as an economic crisis due to the disturbance in economic parameters and then shifts into a political 
crisis while it is predominantly recognized as a crisis of morality and values. The Great Depression in Germany in the 1930s sparked the political movement aimed at changing the German government and establishing the National Socialist government of Adolf Hitler. We remind that the crisis was caused by impoverishment, and an all-time high inflation, when the misery index skyrocketed. Germany resolved its problem of poverty with no regard for the means and methods used, to the detriment of the whole world. The problem of poverty apocalyptically came down on other countries and peoples. The whole world felt the consequences of the disregard for other people, political beliefs, and races. This led to the death of millions of Jews and other people that the Germans qualified as the culprits for their own impoverishment. Almost all societies, including America, were dragged into the maelstrom of World War II and an overall crisis with unforeseeable consequences. This confirms the assumption that poverty can cause crises and destabilization on an overall scale.

Society faces different kinds of crises, manifesting themselves as conflicts, anomies, wars, revolutions, and dysfunctions. Every manifestation of crisis threatens social originality, self-sufficiency, and uniqueness. A society entering a crisis is initially characterized by the emergence of some of its forms, including an economic, political, moral, religious, ecological and value crisis, which then leads to an uncontrollable process ending in an overall crisis. The period of intensive social development in the twentieth century saw the crisis reaching apocalyptic proportions, manifesting itself as a global crisis in the form of two world wars, the global economic crisis, and the global environmental crisis. The crisis is becoming a general diagnosis of the contemporary world, both its prosperous regions and the parts of the world that are classified as underdeveloped.

Poverty encourages a "new economy," the economy adapts to new needs, and the new needs create a new economic environment. Poverty and the direct struggle for bare survival in structurally new economic circumstances cause the appearance of gray, flea-market, and second-hand economies. Highly developed technologies and their corresponding economy naturally bypass unstable regions and regions in a state of political and economic disorder or appear in a way that does not ensure overcoming poverty, but maintains a situation of economic dependence of both the economy and the individuals. The crisis that shows its true face in poverty threatens to open a Pandora's box of widespread social instability.

\section{Social inequalities and risks}

The modern world abounds with social inequalities. Branko Milanović, one of the most esteemed researchers of the World Bank in charge of studying global inequality, argues that studying the rich and the poor and studying the history of global inequality represents the modern cross-section of global, national, and regional aspects of inequality. The author does not only analyze social inequality and poverty through the lens of unequal income distribution, but also points to the fact that social inequalities need to be connected to intrasocietal issues of stability, 
development, social justice, repression, and human rights, including the phenomena of globalization and international migration.

Milanović is an economist, but he also talks about the social consequences of inequality through the lens of historical and temporal perspectives, geographical distribution, and geopolitics. The author's viewpoint is that inequalities are not only the result of the market, but of social and political power distribution as well; therefore, one can not only influence them, but also track their development in a historical context (Milanović, 2011).

"Inequality among individuals within a nation," "Unequal nations - inequality among countries of the world," and "An unequal world - inequality among the citizens of the world" are the three aspects of inequality that are analyzed in a complex social context. The author also explains the key economic theories behind the study of the concept of inequality: Pareto's Iron Law of distribution and development, Gini indicators and Kuznetsov's U curve of development. Milanović discusses the usefulness of these theories and indicators in modern terms, particularly focusing on theories stating that inequalities are a side effect of development. It is certainly worth noting the author's observation that the survival of such a high level of inequality, despite international capital liberalization, is in opposition with the predictions of neoliberal models. Social development, history, and social mobility of the population condition inequalities within a nation. Simultaneously, this is the type of inequalities "that concerns us the most" as members of the community.

Wealth redistribution is an instrument the state has at its disposal to stop income inequality becoming too large. A portion of the rich households' wealth is transferred to the poorest ones through income taxes or VAT. Financing child allowances and other state social benefits and allowances is a certain road towards a welfare state, a functioning state in which poverty is reduced.

Inequalities are also visible when comparing nations. The industrial revolution and globalization and an increase in the number of nations after decolonization and the fall of the Berlin Wall created measurable economic parameters which enable the measurement of living standards in national states. The increase of income of a large number of people within China and India, as the most populous states, has a significant impact on poverty reduction and prosperity in these countries, as well as the global reduction of inequality.

Milanović critically examines globalization and the idea that the poor nations will be the biggest beneficiaries of the global economy and the transfer of knowledge. As an ideological counterweight, he cites the Lucas paradox-a tendency of capital to return to the country of its origin or exclusively to higher income classes. This movement, which is opposite to the proclaimed direction, is conditioned by a slower knowledge transfer towards poor countries due to the high prices of its introduction, and the need for specialized experts and labor from developed countries, causing an increased return in capital. Even when the transfer of technologies and knowledge is successful, there is still the fact that the availability of consumer goods, such as mobile telephony and the Internet, does not make a poor person rich if his/her society is not making progress in terms of economic and social development. 
The Marxist theoretical approach to the interpretation of social inequality is facing a severe challenge when it attempts to interpret contemporary class distinctions, social inequality, and poverty. Today, the international "locational" differences in inequality are increasing significantly more than the class differences within a society. The author calculates that the poorest Americans are richer than twothirds of the world's population while the richest people in developing countries are comparable only to the poorest Americans. Today, a person working in a relatively rich society, regardless of class affiliation, is in a much better position and faces a smaller risk of social exclusion.

Developing countries are becoming the "new proletariat" and are in a dependent position in relation to the owners of capital. The differences between developing countries are also growing, particularly in the case of their leading membersIndia and China. When it comes to income growth opportunities, $60 \%$ depend on the country of birth, the parents' class and social mobility within the society both account for $20 \%$, which leaves only $20 \%$ for the contribution of work and personal success. This distribution of opportunities for income growth creates the need for the country and the individual to rapidly advance or for the individual to emigrate, making global inequality the source of growing mass illegal migrations.

Modern society is divided into the extremes of the globally rich and the globally poor, which has led to the emergence of socially unsustainable migration, and the author pays special attention to the understanding of this phenomenon in his book The Two Faces of Globalization (Milanović, 2007). Within this context, he singled out global migration "hotspots," locations with the greatest differences among nations, making them points of enormous migration pressures. This primarily applies to the borders between US and Mexico, Morocco and Spain, Turkey and the Middle East, and Libya and Italy. He cites the lack of future perspective in poor societies as the prevailing motive of youth migration, but he also describes the brutal way the EU is defending its "Mediterranean Wall"- the wide belt of the Mediterranean Sea. More than any other example given in the book, this example illustrates the division into the "globalized world free for the flow of goods" and the inability of human mobility, and emphasizes the fear that growing inequality will cause the continued growth of the number of migrants with difficult experiences, often ending in death.

For the author, inequality in the world is a fact. He believes that globalization causes income distribution to exceed the level of a national question in the context of the general interactions between nations. This special area of interest of the author is thoroughly described in the book "Separate Worlds-Measuring International and Global Inequality." The results of extensive analysis of data between 1988 and 2005 show a high level of global inequality, which is on the increase and is almost twice as large as its level in individual nations. Although there is no government to assume social responsibility, global inequality leads to socially unsustainable migration, while it is responsible for political instability on a local level. Local poverty is increasingly a reflection of global inequality, and this high level of inequality leads to global instability. The confirmation of this claim comes in the form of the migrant crisis and global epidemics. The author points out that the cosmopolitan responsibility 
is equal both in the case of local and global inequality. In other words, measures to decrease globally caused poverty and inequality are as important as steps to reduce differences on a national level. The true antimigration struggle is about improving the living conditions in the migrants' countries of origin, i.e., to decrease the differences between nations and strengthen the middle class on a global scale.

The analysis of social development is also significant-investing in human capital through education and redistribution decreases inequality. Regarding the analysis of the relationship between inequality and development, one must highlight the existence of good and bad inequalities - the relationship between the required resource redistribution and the impact of transfers on economic efficiency, inequality, and economic development. Small inequalities can certainly be stimulating in conditions of social mobility and competition. In this regard, the author of the book discusses the value concept of "economic justice," which considers that even a lower economic profit, if distributed more fairly, is more desirable over extremely unevenly distributed profits in a society. The population is more willing to accept a poorer but a more egalitarian society than one marked by extreme social injustice. A special place is certainly given to the analysis of the last global economic crisis, i.e., its causes in the USA, which the author attributes to the long-term stagnation of the middle class. The politicians have tried to resolve the politically undesirable stagnation of the middle class, a promoter of the "American dream," through cheap loans which maintained a seemingly high level of consumption. The debt of American households constantly increased from $48 \%$ of the GDP in the early 1980 s to nearly $100 \%$ at the time the crisis erupted in 2008, which means it doubled in a short period of time. A more uniform and stable development in the previous decades would not have required the measures used today to sustain the social and political state of affairs, and would have certainly prevented the crisis from erupting in the world.

Having this in mind, the contrast between a noticeable concern for the fight against poverty and real solutions to the problems of inequality is still existent today. This struggle to reduce poverty and inequality is sometimes only declarative and usually does not change the distribution of income and power structures, thus only temporarily moving a number of people out of poverty, but still perpetuating the social space where the production of the poor continues.

According to theorists analyzing this social phenomenon, poverty is becoming increasingly difficult to define in modern conditions. Different attitudes are attributed to different methods of determining the poverty line, different estimates of the population living in poverty, and different social policy programs. Poverty is understood as an absolute or relative category, and objective or subjective criteria are used to determine who is poor. Recent sociological studies mainly speak about its multidimensional character: hunger and malnutrition; poor health; limited or no access to education and other existential services; increased mortality, including mortality from disease; homelessness and inadequate housing conditions; and an insecure environment, social discrimination, and isolation (Tomić, 2007). Social exclusion is used as a euphemism for poverty. The classic concept of poverty is being replaced in studies and strategic documents of the European Union. "The concept 
of social exclusion is an analytical instrument for the research and suppression of poverty which is better attuned to a new, postindustrial society because it provides a wider perspective on the deprivation that comes from poverty and shows how social structures generate poverty" (Eurostat, 2010). Unlike poverty, which is measured by material indicators or sources of income, social exclusion involves a holistic concept centered around value patterns that are formed based on poverty and hinder the integration of these groups as key causes that lead to a spiral of social decline (Eurostat, 2010). In official documents of Serbia, this concept is explained as "a dynamic process that allows all individuals and social groups to fully participate in the economic, social, and cultural trends, and achieve an adequate living standard. The process should allow greater citizen participation in decision-making, especially regarding the decisions that affect their well-being and exercising their human rights" (Njalker, 1995).

The political crisis is manifested in the parliamentary and presidential elections, and the post-election combinations resulting from the (im)possibility of forming institutions, the inability of the institutions to function, and a crisis in their functioning. The society is nearly polarized and politically divided along several dimensions. A high rate of abstinence from expressing one's political attitudes is a visible expression of the social crisis in the political sense. On the other hand, the political crisis is directly reflected in the economic and other aspects of social life. Basically, the economic crisis leads to the impoverishment of the society and opens a way to political instability, corruption, and conflict.

\section{Poverty and the crisis in Serbia}

The global economic crisis impacted the economy in Serbia in different ways - by reducing incentives, investments, and wages. During that period, insolvent companies and entrepreneurs owed the banks a total of 91 billion dinars and their debt to the state amounted to 65 billion dinars. Small businesses had the biggest problems. In the spring of 2007, IMF experts concluded that the three biggest problems of Serbia were:

a huge current account deficit of the balance of payments;

an oversized public sector that was not transformed;

an external debt and high foreign indebtedness (Jotić, Tegeltija and Lovre, 2011).

During the crisis, Serbia faced a decrease in foreign currency inflow from abroad and the inability to get loans. As a result of the crisis, the inflow of foreign currency from the sale of enterprises to foreigners, greenfield investments, and the export of goods and services was considerably reduced. This resulted in a total outflow of foreign currency that was significantly higher than their total inflow, leading to a noticeable depreciation of an extremely overvalued dinar. These mechanisms enabled the crisis to additionally exacerbate the Serbian economic problems tied 
to the inability of sustaining the existing level of income and standard in the long run, and the growth of insolvency. "The sustainability of the existing income and standard was jeopardized because of the low level of export, low foreign investments, fewer options for borrowing, an unrealistic exchange rate of the dinar, the economic isolation of the country, etc." (Bošnjak, 2011). Insolvency appeared due to the debt of the country towards other companies and the increase of debt among businesses, taking loans in a situation when sales were dropping, the decrease in the value of the dinar that jeopardized solvency due to the late collection of goods and services sold, the clients' poor estimate of the business risk, falling employment rates, businesses struggling to alleviate losses, and the inability of businesses and the economy to service their debts due to the depreciations of the dinar. The crisis was felt both by businesses and households. Falling share prices of the top Serbian companies indicated that the Serbian economy was in crisis. A decrease in the available money and the increase in prices coupled with a decreasing purchasing power inevitably took its toll on sales since the population generally focused on buying essential groceries.

The global economic crisis spilled over into Serbia from developed countries. This process took place through two channels. The first channel of transmission of the global economic crisis from the developed countries into Serbia was the reduction of available loans and the increase in the price of borrowing. The second channel was the reduction in the influx of capital which depreciated the exchange rate of the dinar against the euro and the dollar.

The economic crisis that engulfed Serbia was primarily manifested through a reduction of the gross domestic product, a drastic fall in industrial production, a drastic fall in construction activity, a significant drop in investments, a high reduction in exports, the import of production materials, especially equipment, a huge insolvency in the economy, a growing number of companies with blocked accounts, a sharp increase in the number of unemployed people, etc. All this had a direct impact on the growth of poverty and the expansion of groups of people who were impoverished or were at risk of poverty.

Poverty in Serbia reflects uneven social development, many conflicts and wars, civil division, wrong investments, changes in economic structure, changes in property relations, a low GDP, borrowing under unfavorable economic conditions, inflation, hyperinflation, transition, a national economic and political reform, etc. What characterizes the state of transition the Serbian society is in are the decades of instability, both at the political and the economic level. The typical Balkan syndrome of the disorder of social relations was the cause of the crisis in Serbia as well. The 1990s saw the restructuring of the economy suffering the consequences of failed privatizations and a large number of workers who lost their jobs and regular income, which led to the impoverishment of the population from different social strata, as well as the departure of a large number of people from Serbia, especially the educated and young ones, which is popularly referred to as "brain drain."

The social crisis in Serbia took place along with the impoverishment of the population and the state. A decline in living standards was caused by shutting down 
corporate giants, rising numbers of unemployed residents without a livelihood, gray economy activities (illegally, without a tax registration), the reduction in the GDP, and a growing number of social benefits recipients. The decline in living standards led both to an overall social crisis and crises that were expressed in different forms. A social crisis caused by economic parameters was recognized in Serbia through an increase in unemployment rates of over $20 \%$; an increase in the number of retired people relative to the number of workers; the slowing down of economic growth; the increase in the budget deficit; the reduction in the number of active businesses and shops; the growth of the foreign trade deficit; the growth of the foreign trade debt to over 23 billion euros; the growth of the public debt; a decrease in the population's standard of living directly leading to an increase in the number of extremely poor persons; the growth of regional differences in development; the decrease in the value of the national currency etc. Economists consider the main indicators of the economic crisis to be the slowing down of the GDP growth rate, the decline in industrial production and construction, the reduction of foreign trade, the reduction of investments, the reduction in the inflow of foreign capital, an increase in inflation through the rise of consumer prices, the decline in economic rating, and the growth of the unemployment rate and the misery index (Kovačević, 2010).

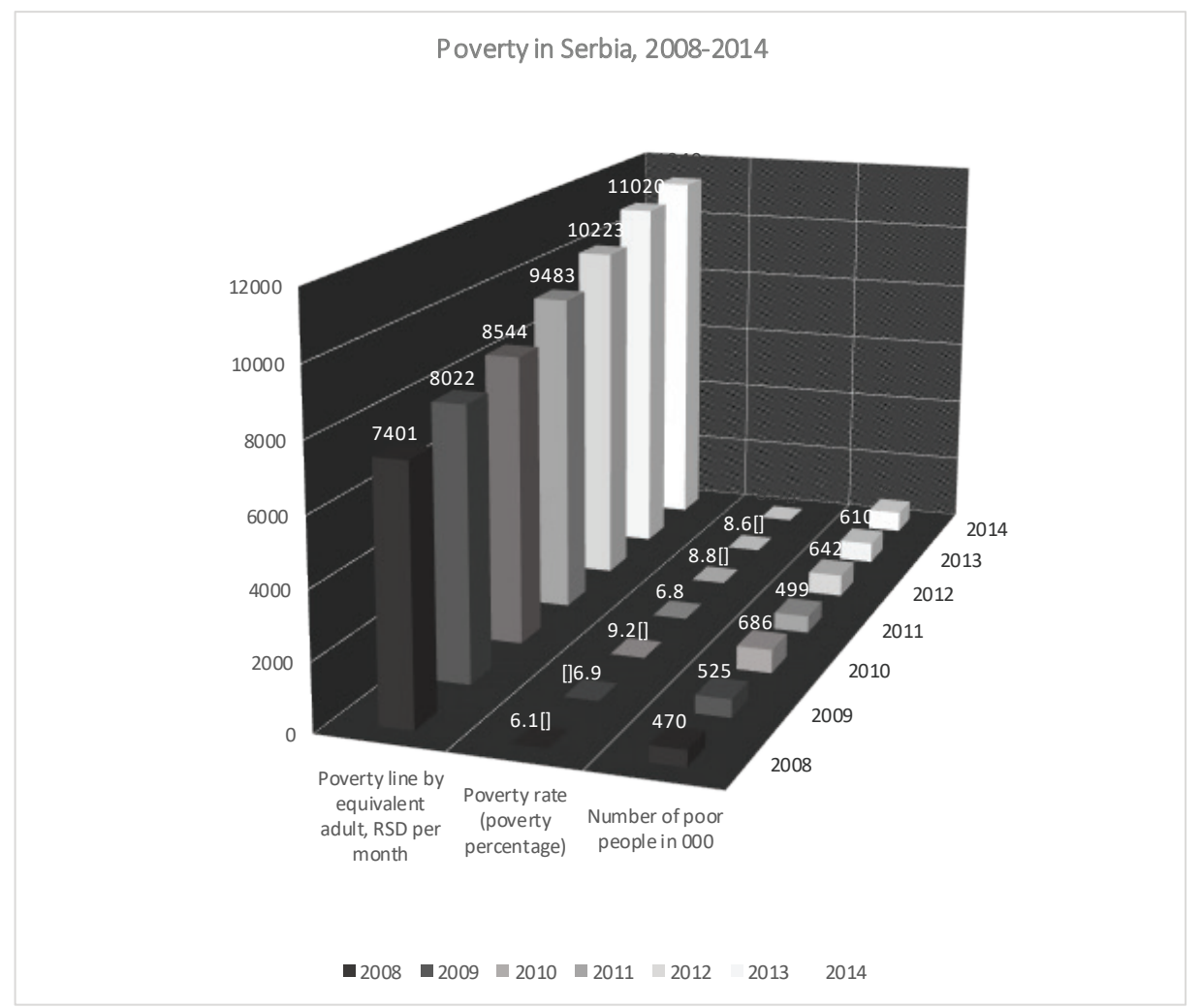

Figure 1. Line and rate of poverty in Serbia (2008-2014) 
Transition in Serbia was accompanied by several processes that lead to the stratification and impoverishment of the population. The changes that occurred in Serbia are defined as "blocked transition" or "delayed transition." Corruption, partocracy, the absence of political culture, underdevelopment of institutions, economic deprivation and impoverished citizens referred to as "transition losses" represent the essential characteristics which panned out in the society throughout the different levels of the crisis. "Crony capitalism" (Stojiljković, 2014), "capitalism repeating the primitive accumulation of capital," or "wild capitalism" (Vidojević, 2010) point to the essence of the social changes that have led to the impoverishment of the population, the process of social exclusion, and social crises.

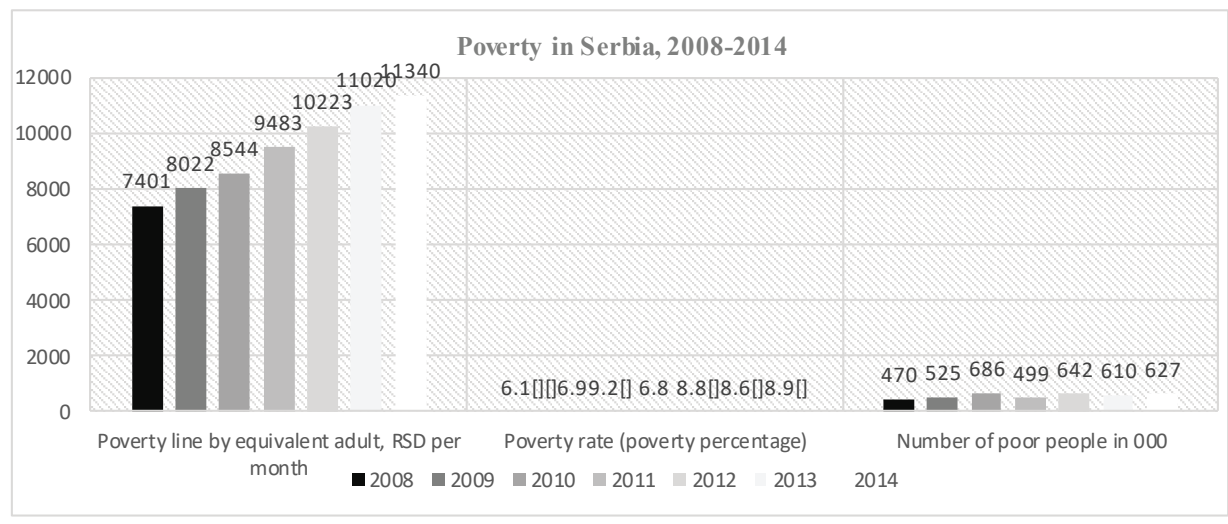

Figure 2. Poverty in Serbia, overview (2008-2014)

The risk of poverty is increased by unemployment, not having a steady job, a poorly paid job, a low level of education and skills, and the size and type of the family. Large families or single-parent families are at greater risk of poverty. Women are at higher risk of poverty than men since they are often underpaid and discriminated against at work. Disability and poor health limit access to employment. Ethnic minority groups, the Roma people, and migrants are discriminated against and have fewer opportunities for social inclusion, employment, and education. They often live in isolated enclaves, inhabiting makeshift residences that lack minimal hygienic conditions, and do not have access to basic services. Uneducated people, Roma, children from large families, people with disabilities and female population are at the highest risk. There was no significant reduction of poverty rate in the period from 2006 to 2016. In 2016, 7.3\% of population was absolutely poor. The reduction of the number of absolutely poor people is a consequence of the reduction of total population. Approximately 500,000 people do not have enough funds to cover basic living needs. This shows that Serbia is a society with a high risk of poverty. 


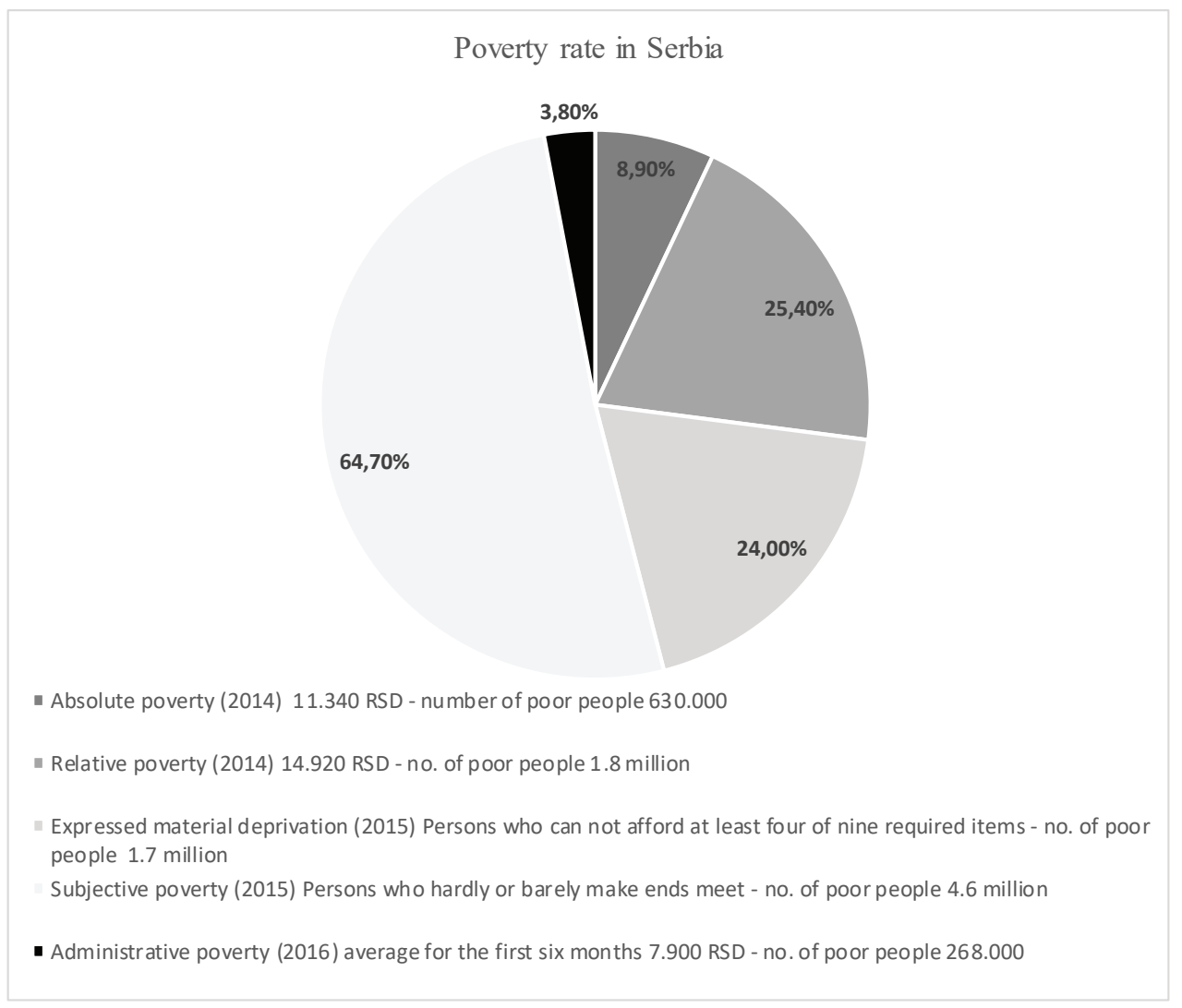

Figure 3. Levels of poverty in Serbia (2014-2016)

The economic crisis directly affects individual impoverishment, social stratification, the collapse of social values, and the emergence of political instability and crisis. The economic and political crisis influence education in the cruelest possible way. If the educational system is a society's most organized means for transferring knowledge, desirable values, and culture, then a crisis of the society leads to the expression of all the visible and hidden aspects of the school system crisis.

The educational crisis is reflected in the phenomenon of "brain drain." This phenomenon is observed as a serious indicator that a society is experiencing undesirable social anomalies. The phenomenon is recognized not only as a steady depletion and collapse of the society in which it occurs, but also as one of the causes of a general imbalance in social development. It is measurable in realistic economic parameters, which illustrate the direct harm for the society it occurs in. Serbia is among the countries with the highest rate of "brain drain." On the one hand, the politicians appeal for the harmful process to be halted while, on the other hand, the statistical data undoubtedly confirms the fact that since 2000 many highly educated professionals left Serbia. According to official data, this amounted to $2 \%$ of the population in the 1980 s. This number tripled in the 1990 s, only to reach $20 \%$ in 
2000. According to the US Agency for International Development (USAID), Serbia is at the very top of the list of countries ranked according to the "brain drain" rate-it is in second place, behind Guinea-Bissau. Statistics show that 500,000 professionals have left Serbia. Results of a research performed by the Student Union of Serbia state that every third student is planning to leave the country. Highly educated people are leaving the country, regardless of whether they are employed or unemployed. It is an indicator not only of a crisis of the society, but of the educational system as well.

\section{Instead of a conclusion: education as a resource}

for the reduction of poverty, social inequality, and social crises

The crisis affected the new EU member states differently than the countries in the Eurozone. Most of these countries recorded a smaller decline in the growth rate of their gross domestic product. The reasons for the better position of these countries are numerous investments from abroad and by the IMF. Apart from that, a large number of workers from these countries went to work in countries that are in the Eurozone, which was one of the benefits in terms of solving social problems. The crisis affected Greece, Ireland, and Spain the most. The EU created a policy that included crisis management measures and systemic measures to ensure fiscal sustainability, long-term growth, monetary balance, revitalization and strengthening of the financial system, as well as aiding the most vulnerable members.

The economic crisis that engulfed Serbia was primarily manifested through the reduction of the gross domestic product, a drastic fall in industrial production, a drastic fall in construction activity, a significant drop in investments, a high reduction in exports, huge insolvency in the economy, a growing number of companies with blocked accounts, a sharp increase in the number of unemployed people, etc. The crisis has strongly affected the decrease in the inflow of foreign direct investments into Serbia. The reduced influx of capital depreciated the exchange rate of the dinar against the euro and the dollar.

In a modern society, education is becoming a dominant channel of social mobility, a resource to reduce social inequality, and a means to solve the problem of poverty and the social exclusion of individuals and social groups. The democratization of the education system enabled entire social strata to move up the scale of social mobility. Unemployment and inadequate educational policy powered social segregation and the creation of marginal social groups, which additionally complicates the crisis of the society. The unemployed, educated and highly educated people are changing the role of education in the social structure. When education and being educated lose social power and significance, and some new values gain significance, this creates space for socially hazardous behavior, leading the society to crisis, conflict, and tension.

The current and future social crisis cannot be resolved without fully considering the issue of education as an important economic factor, beginning with the type of social policy that is in place or not, the educational system and the way its problems are solved, to planning and the reform of the educational system. If the economic crisis of the society is solved by 
reducing the funding for education and cutting investments in the educational system, and the political crisis is solved by interfering with the autonomy of the educational institutions and attempting to impose political influence on schools and universities by introducing dictated reforms without considering any expert findings and realistic needs, the crisis can only deepen with unforeseeable consequences for all generations and the whole society. It is more than justified to use economic and sociological expertise in understanding the problems of education in modern society, not only through analyzing all the aspects of a social crisis, but also by fueling the efforts in finding ways for their resolution.

\section{References}

Allen, F., Carletti, E. (2009) “The Global Financial Crisis: Causes and Consequences”. Available from:

http://www.bm.ust.hk/gmifc/Prof.\%20Allen\%20\%26\%20Carletti_The\%20Global\%20 Financial\%20Crisis.pdf [Accessed $15^{\text {th }}$ February 2017].

Aslund, A. (2002) Building Capitalism. Cambridge: Cambridge University Press.

Bošnjak, M. (2011) Globalna finansijska i ekonomska kriza 2007-2010. godina-uzroci, posledice i poruke. [The global financial and economic crisis of 2007-2010-causes, consequences and messages]. Beograd: Ministarstvo finansija.

Christie E. \& Holzner M. (2003) "The Dark Side of the Balkans" in The Vienna Institute Monthly Report (Podkaminer, L., ed.). Vienna: The Vienna Institute for International Economic Studies.

Eurostat (2010) Combating poverty and social exclusion 2010 edition. A statistical portrait of the European Union. Available from: https://ec.europa.eu/employment_ social/2010againstpoverty/export/sites/default/downloads/Publications/Statistical_ portrait_of the_EU2010.pdf [Accessed 20 $0^{\text {th }}$ February 2017].

Gligorov, V. (2005) "Privreda pod represijom”. Ekonomist magazin 276(5): 18-23.

Greskovits, B. (1998) The Political Economy of Protest and Patience. Budapest: CEU Press.

Johnson, S. \& La Porta, R. et al. (2000) Tunneling. The American Economic Review 90(2): 22-27.

Jotić, J., Tegeltija, M., Lovre, I. (2011) Savremene tendencije i kriza finansijskog sektora u Srbiji. Škola biznisa 2: 90-99.

Kovačević, M. (2010) Uzroci duboke ekonomske krize u Srbiji. Škola biznisa 3: 1-14.

Mijatović, B. (2005) “Opšti pregled tranzicije u Srbiji”, in Četiri godine tranzicije u Srbiji (Begović, B. et al., eds.). Beograd: Centar za liberalno demokratske studije.

Milanović B. (2011) The Haves and Have Nots. A Brief and Idiosyncratic History of Global inequality. New York: Basic Books.

Milanović, B. (2007) Dva lica globalizacije. Beograd: Arhipelag.

Milić, A., Čičkarić, Lj. (1998) Generacija u protestu. Beograd: Institut za sociološka istraživanja Filozofskog fakulteta Univerziteta u Beogradu. 
Porter, M., Schwab, K., Sala-i-Martin, X., López-Claros, A. (2004) The Global Competitiveness Report 2004-2005. London: Palgrave Macmillan.

Saul, J. R. (2011) The Collapse of Globalism and the Reinvention of the World. Beograd: Arhipelag.

Stojiljković Z. (2014) Šta nam se to dešava? Available from: http://sindikalizam. org/2014/07/13/sta-nam-se-to-desava/ [Accessed $15^{\text {th }}$ February 2017].

Tomić, V. (2007) "Siromaštvo i socijalna isključenost - osnovne definicije i indikatori”. Sociološka luča 1/2: 149-166.

Vidojević Z. (2005) Kuda vodi globalizacija. Beograd: "Filip Višnjić”/Institut društvenih nauka.

Vidojević, Z. (2010) Demokratija na zalasku. Beograd: Službeni glasnik/Institut društvenih nauka.

Walker, R. (1995) "The Dynamics of Poverty and Social Exclusion", in Beyond the Threshold (Room, G., ed.). Bristol: Policy Press.

Zorid, M. (2010) Međunarodne krize. Vojno delo 62(4): 292-333.

\section{СИРОМАШТВО И ДРУШТВЕНА НЕЈЕДНАКОСТ КАО ФАКТОРИ СОЦИЈАЛНЕ ЕКСКЛУЗИЈЕ}

Ancтракт: Рад се бави квалитативном анализом сиромаштва и социјалне неједнакости у савременим друштвима и облицима социјалне искључености појединаца, породица и друштвених група. Показатељи сиромаштва, узроци сиромаштва, индекс беде, животни стандард, друштвено раслојавање и социјална искљученост су неке од економских, а такође и социолошких категорија које су мерљиви и примењиви фактори у анализи социјалних услова. Сиромаштво, социјална неједнакост и социјална искљученост дају слику друштва и указују на могућа ограничења у друштвеном развоју, потенцијалне сукобе, поделе, отворене и прикривене тензије. Економски показатељи, као што су БДП, индекс индустријске производње, инфлација, незапосленост, потрошачка корпа заједно са нивоом образовања становништва, нивоом достигнуте демократије, политичке стабилности и оријентације на друштвено благостање (одговорна социјална политика), могу бити основа за анализу перспективе социјалне укључености појединаца, породица и друштвених група у одређеним друштвима. Рад има за циљ да изврши анализу идеалних типова социјалних модела, као и да предложи мере социјалне политике за превазилажење сиромаштва и социјалне искључености, као растућег социјалног проблема савременог света. У овом се тренутку читаве земље централне Африке суочавају са ситуацијом у којој милиони људи умиру од глади, што је најекстремнији облик сиромаштва. Ова друштва су скоро у потпуности искључена из светске заједнице. Начин њиховог укључивања је ангажовање у хуманитарним акцијама на обезбеђењу хране, питке воде и здравствених услуга. Ово је прва фаза стварања услова за социјалну укљученост, а следећи ниво је стварање услова за образовање становништва.

Кључне речи: сиромаштво; друштвена неједнакост; социјална искљученост 